\title{
Application of chlorine dioxide for secondary effluent polishing
}

\author{
"F. Vaezi, K. Naddafi, F. Karimi and M. Alimohammadi \\ Department of Environmental Health Engineering, School of Public Health \\ and Institute of Health Research Center, Tehran University of Medical Sciences, Tehran, Iran
}

\begin{abstract}
There are still many difficulties for developing the projects of using treated effluents. In this study, the efficiency of chlorine deoxide in the process of preparing the effluent of Sahebgharanieh Plant of Tehran for reuse purposes has been determind. Major results are as follows: Total COD reductions resulted from effluent treatment by $\mathrm{ClO}_{2}$ solutions having concentrations equal to $1 / 4,1 / 2$ and $1 / 1$ of COD samples at one hour contact time have been about $42 \%, 49 \%$ and $59 \%$ respectively. Total suspended solids were also reduced by treatment with $\mathrm{ClO}_{2}$ solutions having the certain concentrations mentioned, and the reductions were about $37 \%, 47 \%$ and $58 \%$ respectively. Besides total and fecal coliforms results indicated that $\mathrm{ClO}_{2}$ apllied was quite efficient in effluent disinfection. The conclusion is that reasonable reductions would be expected in the amounts of remained major pollutants and so reuse applications for some non-potable purposes may become possible. The acidification of chlorite has been used for $\mathrm{ClO}_{2}$ generation as it is better suited to small treatment systems.
\end{abstract}

Key words: Wastewater treatment, chlorine dioxide, chemical oxidation, secondary effluent

*Corresponding Author, E-mail: for_vaezi@yahoo.com

\section{Introduction}

Chlorine dioxide $\left(\mathrm{ClO}_{2}\right)$ which was first used in drinking water treatment is an oxidant increasingly of interest for industrial and wastewater treatment (Eckenfelder and Bowers, 1994). It has become a disinfectant alternative to chlorine and ozone because it offers the prospect of disinfection without the production of trihalomethanes and bromates so it is gaining acceptance as a water treatment promise (Otterholm and Jadesjo, 2000). As an oxidant, $\mathrm{ClO}_{2}$ is generally considered for reuse strategies, because it is more effective than chlorine in inactivation of most pathogens (Metcalf and Eddy, 2003). Besides, its biocidal properties are not influenced by $\mathrm{pH}$ and it is a more powerful oxidant than chlorine (Reynolds and Richards, 1996). However, the findings of Stanford group indicate that $\mathrm{ClO}_{2}$ is only slightly superior to chlorine as a bactericide but it is a much superior virocide. Compared to ozone which is the strogest oxidant of the common disinfecting agents, $\mathrm{ClO}_{2}$ has the advantages of easier generation in point of use and a longer life of the preservation (White, 1992).

Interest in $\mathrm{ClO}_{2}$ for chemical waste treatment is of more recent origin to reduce and eliminate the environmental problems caused by the discharge of waste streams without inadequate treatment (Eckenfelder and Bowers, 1994). In particular, oxidation offers one of the few methods for removing odor, color and various potentially toxic organic substances, often found in wastewaters (Jackman and Powell, 1991). $\mathrm{ClO}_{2}$ is equally effective in secondary nonnitrified or nitrified effluents for disinfection purposes and the increased disinfection effectiveness seen in filtered versus nonfiltered wastewaters is not accompanied by any significant change in disinfectant demand (WPCF, 1986). In this article, we discuss the usefulness of $\mathrm{ClO}_{2}$ as a disinfectant and chemical oxidant for secondary effluent polishing. $\mathrm{ClO}_{2}$ production and so its use for wastewater treatment has not already been performed in Iran.

\section{Materials and Methods}

Generating chlorine dioxide

There are several methods available for $\mathrm{ClO}_{2}$ generation. For this study, direct acid system has been used because it was well studied for most small treatment systems (White, 1992). This method utilizes the reaction of a strong acid with sodium chlorite $\left(\mathrm{NaClO}_{2}\right)$. The following reaction which is most accepted for $\mathrm{H}_{2} \mathrm{SO}_{4}$ is: 
$10 \mathrm{ClO}_{2}+5 \mathrm{H}_{2} \mathrm{SO}_{4} \rightarrow 8 \mathrm{ClO}_{2}+5 \mathrm{Na}_{2} \mathrm{SO}_{4}+$ $2 \mathrm{HCl}+4 \mathrm{H}_{2} \mathrm{O}$

Figure 1 is a schematic diagram of the manual small generation system arranged for this study. It was also needed to apply a compressed air supply to transfer the generated $\mathrm{ClO}_{2}$ gas to the final flask. This flask was put in an ice bath to preserve the strength of the prepared stock solution. Both sulfuric and chloridric acids which were used in the preliminary tests, showed favorable results and the concentration of $\mathrm{ClO}_{2}$ solutions prepared was enough to use in wastwater treatment. The stock solution was then stored in a glassstoppered dark-colored bottle in a refrigarator.

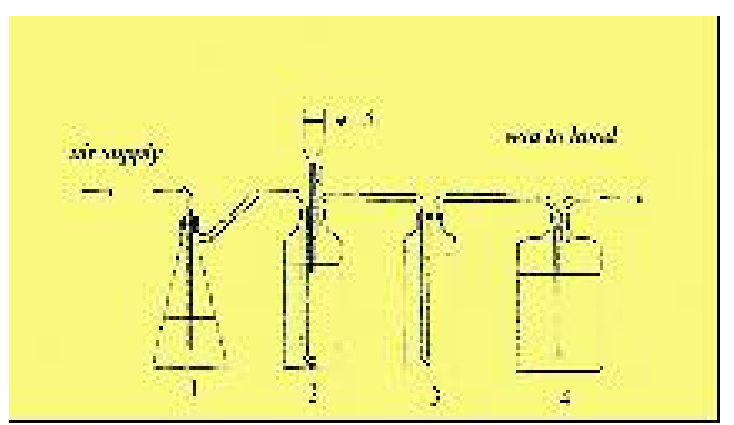

Figure 1: Manual feed equipment arrangment for generating $\mathrm{ClO}_{2}$

1. aspirator flask

2. gas generating bottle (reaction vessel)

3. collecting bottle containing $\mathrm{NaClO}_{2}$ solution (14/l)

4. collecting bottle containing water for gas absorbsion

5. separatory funnel containing $10 \% \mathrm{H}_{2} \mathrm{SO}_{4}$

\section{Methods of $\mathrm{ClO}_{2}$ control}

As it was already mentioned, $\mathrm{ClO}_{2}$ gas produced in direct acid system was absorbed in enough distilled water. The $\mathrm{ClO}_{2}$ concentration thus, prepared can be determined by iodometric method as outlined in Standard Methods (APHA, 1995). However, yield determination can be done only when laboratory apparatus for determination of chlorite and chlorate ions are available, because for calculating $\mathrm{ClO}_{2}$ yield by the following equation (Aieta and Hernandez, 1984), the concentrations of these ions should have to be known :

$$
\mathrm{ClO}_{2} \text { yield }=\frac{\left[\mathrm{ClO}_{2}\right]}{\left[\mathrm{ClO}_{2}\right]+\left[\mathrm{ClO}_{2}^{-}\right]+0.808\left[\mathrm{ClO}_{3}^{-}\right]} \times 100
$$

\section{Wastewater sample and characteristics}

The samples were collected from Sahebgharanieh Treatment Plant in Tehran.

This Plant which is located in north part of Tehran is an extended aeration system having 2 aeration basins. The wastewater is treated with an average flow of $25 \mathrm{~m}^{3} \mathrm{~h}^{-1}$. Characteristics of secondary effluent samples before and after treatment by $\mathrm{ClO}_{2}$ solutions, were determined according to the procedures outlined in the Standard Methods. The tests were confined to the determination of total COD, soluble COD, total suspended solids (TSS), total and fecal coliforms which all are considered to be the most important pollutants remained in the secondary effluents of conventional plants which do not practice disinfection. The period of this experimental study was performed in Tehran from January 2000 to July 2001. In this period, the Sahebgharanieh Plant was often unabled to produce effluent with BOD and TSS of less than $20 \mathrm{mgl}^{-1}$.

\section{Results}

Figure 2 shows the results of secondary effluent treatment in total COD reduction by $\mathrm{ClO}_{2}$ in different contact times. In Figure 3, the efficiencies of $\mathrm{COD}$ removal by $\mathrm{ClO}_{2}$ in different $\mathrm{pHs}$ could be considered in one hour contact time and results of total and dissolved COD reduction by various amounts of $\mathrm{ClO}_{2}$ solution can be seen in Figure 4. Although the disinfection effect of $\mathrm{ClO}_{2}$ is a well known phenomena, the efficiency of the treatment in reduction of both total and fecal coliforms was determined. The results of this treatment in 60 minutes contact time with various concentrations of $\mathrm{ClO}_{2}$ solutions are in Table 1 . Finaly, Figure 5 shows the results of TSS removal by various amounts of $\mathrm{ClO}_{2}$ solutions in one hour contact time.

Table 1: Reduction of total and fecal coliforms by $\mathrm{ClO}_{2}$ treatment of effluent samples

\begin{tabular}{|cccc|}
\hline $\begin{array}{c}\mathrm{mg} / \mathrm{ClO}_{2} \\
\text { applied }\end{array}$ & $\begin{array}{c}\text { Contact } \\
\text { time } \\
\text { (min.) }\end{array}$ & $\begin{array}{c}\text { Total } \\
\text { coliforms } \\
\text { (MPN/100ml) }\end{array}$ & $\begin{array}{c}\text { Fecal } \\
\text { coliforms } \\
\text { (MPN/100ml) }\end{array}$ \\
\hline 0 & 0 & 100 & 90 \\
\hline $\mathrm{C} / 4$ & 60 & $<2$ & $<2$ \\
\hline $\mathrm{C} / 2$ & 60 & 2 & $<2$ \\
\hline $\mathrm{C}$ & 60 & $<2$ & $<2$ \\
\hline 0 & 0 & 80 & 50 \\
\hline $\mathrm{C} / 4$ & 60 & 2 & $<2$ \\
\hline $\mathrm{C} / 2$ & 60 & $<2$ & $<2$ \\
\hline $\mathrm{C}$ & 60 & $<2$ & $<2$ \\
\hline$* \mathrm{C}=\mathrm{COD}$ concentration of the effluent sample \\
\hline
\end{tabular}




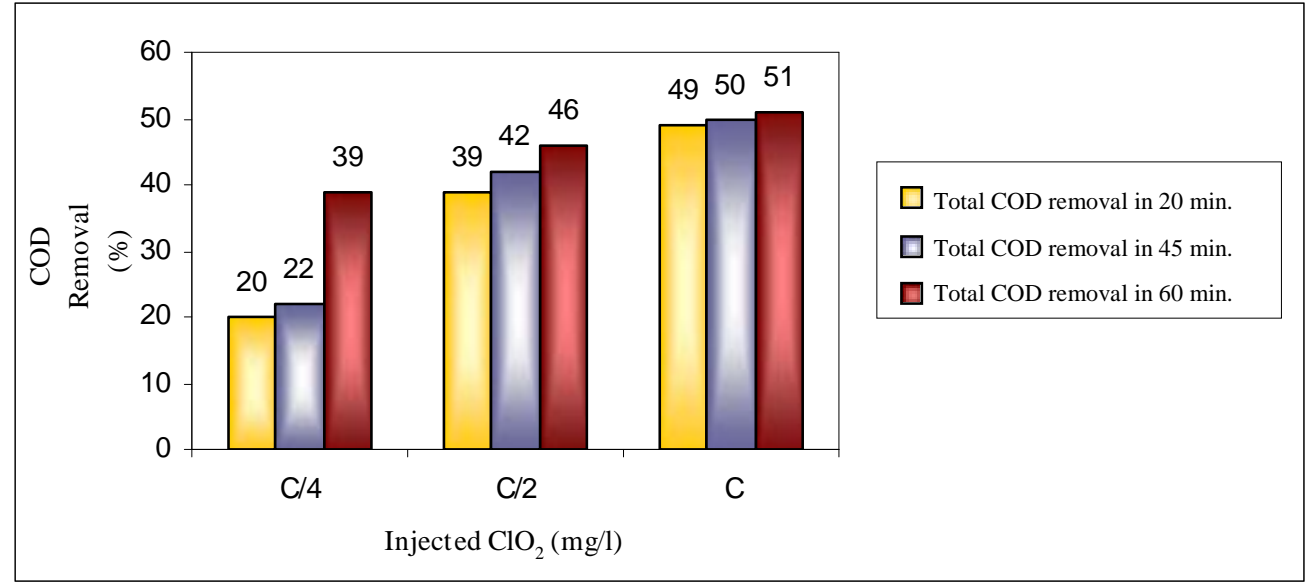

Figure 2: Total COD removal as a function of injected $\mathrm{ClO}_{2}$ in different contact times ( $C=$ influent $C O D$ concentration)

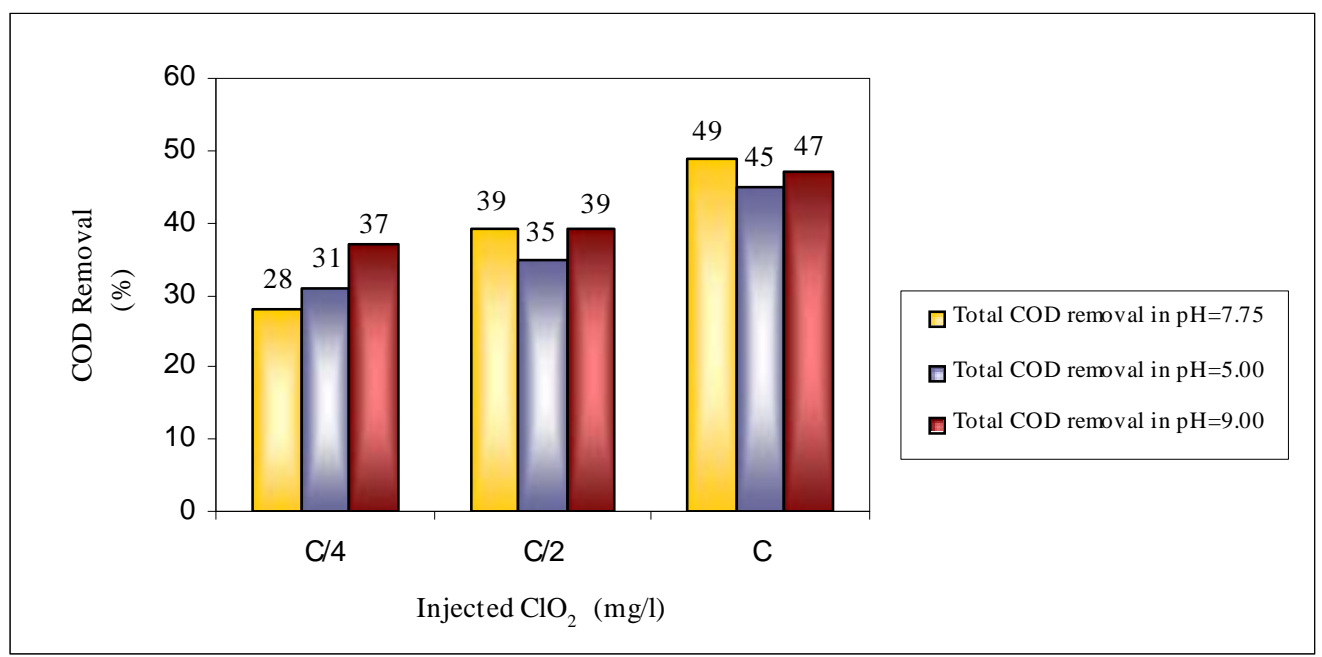

Figure 3: Total COD removal as a function of injected $\mathrm{ClO}_{2}$ in various $\mathrm{pH}_{\mathrm{s}}$ of treatment

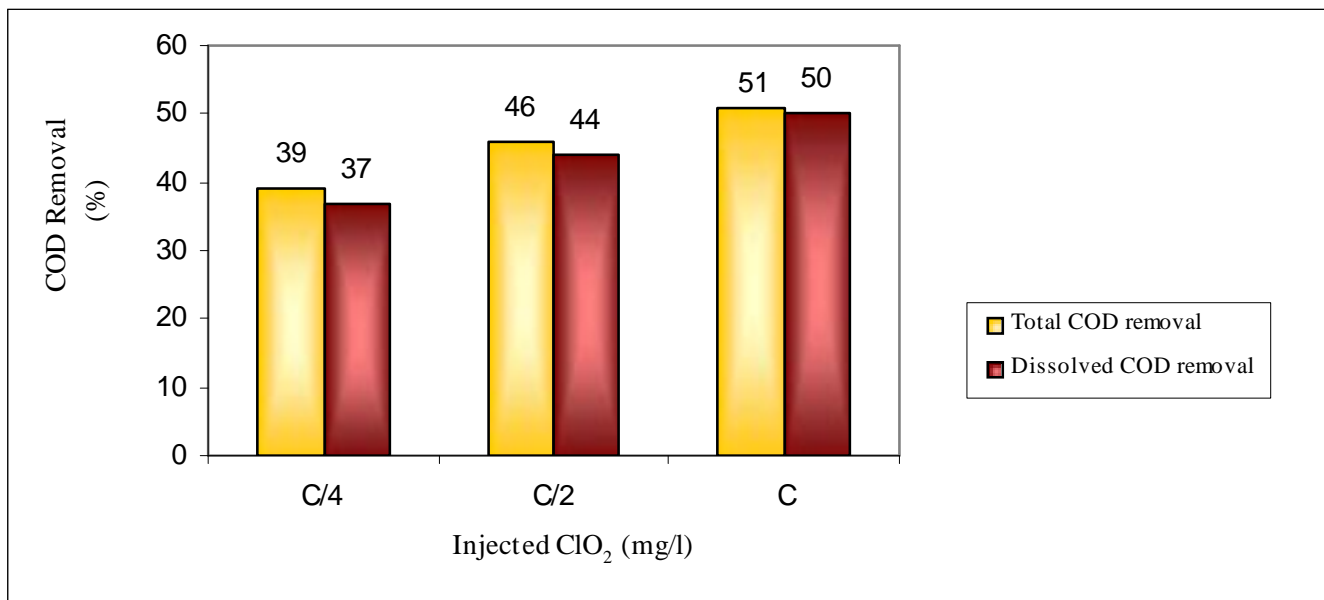

Figure 4: Total and dissolved COD removal as a function of injected $\mathrm{ClO}_{2}$ in one hour contact time $(C=$ influent $C O D$ concentration) 


\section{Discussion and Conclusion}

Most small scale $\mathrm{ClO}_{2}$ generators in industrialized countries use sodium chlorite as the base chemical and sulfuric acid as the chlorite activator (White, 1992). This was the reason of choosing direct acid system for this study. However, some difficulties were experienced and according to the results, the concentrations of $\mathrm{ClO}_{2}$ solutions prepared in the 4 tests were 200,250, 270 and $400 \mathrm{mgl}^{-1}$, whereas it could be at least $250 \mathrm{mgl}^{-1}$ (APHA, 1995). The conclusion is that even if there is only a slight deviation in operating conditions of synthesis, the quality of final solution would be affected. This matter should be considered in all treatment plants that would utilize this method for wastewater polishing. The yield could not be reported for $\mathrm{ClO}_{2}$ generator, because the apparatus needed for determination of the probable chlorite and chlorate produced was not available.

In the study of oxidation power of $\mathrm{ClO}_{2}$ for effluent polishing, 3 contact times of 20,45 and 60 minutes were chosen. Also, three concentrations of $\mathrm{ClO}_{2}$ solutions were used which were as high as the total, half and one forth of the COD concentration of effluent sample under treatment. The best results were belong to the highest amounts of both contact time and $\mathrm{ClO}_{2}$ concentration i.e., more than $60 \%$ removal in COD was achieved by 60 minutes contact to about $30 \mathrm{mgl}^{-1} \quad \mathrm{ClO}_{2}$. However, for reducing the remained COD of secondary effluent to less than $20 \mathrm{mgl}^{-1}$, less $\mathrm{ClO}_{2}$ concentrations and/or contact times were quite sufficient, for example, $15 \mathrm{mgl}^{-1} \mathrm{ClO}_{2}$ in 1 hour contact time or $30 \mathrm{mgl}^{-1}$ in 45 minutes. But, reducing the contact time to less than 45 minutes is not recommended. According to Figure 4, it could be concluded that most of the considered reductions in COD are belong to dissolved fraction of this parameter.

The changes of $\mathrm{pH}$ in common range of 5 to 9 have not appreciable effect on the efficiency of organics removal by $\mathrm{ClO}_{2}$. It seems similar to the accepted fact of independence of disinfecting power of $\mathrm{ClO}_{2}$ to $\mathrm{pH}$ changes.
Disinfection power of $\mathrm{ClO}_{2}$ is a well known phenomena and results of our study also indicate that complying with the standard of less than 2 total and fecal coliforms in $100 \mathrm{ml}$ of effluent would be easily achieved by $\mathrm{ClO}_{2}$ treatment. Besides, organic and microbiological pollutants, TSS (often specified as turbidity) reduction is also recommended for all reuse applications of secondary effluents. $\mathrm{ClO}_{2}$ treatment seems to be successful in complying with this standard too, for the reason that the reduction of about $60 \%$ of remained TSS is possible in 1 hour contact to $\mathrm{ClO}_{2}$ in concentration equal to the amount of COD of treated effluent.

Assessment of advanced treatment of secondary effluent by $\mathrm{ClO}_{2}$ shows the considerable effect of this gas in reducing the remained pollutants of these effluents. Moreover $\mathrm{ClO}_{2}$ has been shown to be effective disinfectant for bacterial indicators at Sahebgharanieh Treatment Plant. Safe production of $\mathrm{ClO}_{2}$ is possible by direct acid system and required amounts for effluent polishing would be reduced by modifying the performance of treatment plants to have a typic effluent (20/20 or less for BOD and TSS) at all times and even further by upgrading them to produce effluents with new standard of 10/10 for example by employing a filtration step prior to $\mathrm{ClO}_{2}$ injection. $\mathrm{ClO}_{2}$ treatment seems to be an acceptable treatment technology to ensure good effluent quality for reuse applications such as agricultural and landscape irrigation and even for all the other urban nonpotable applications, when it is employed for filtered effluents. One final but important point for $\mathrm{ClO}_{2}$ treatment concerns the required time. Because the data on $\mathrm{ClO}_{2}$ in the references are limited, it is recommended to perform site specific testing to establish appropriate dosage ranges. However, the contact time for $\mathrm{ClO}_{2}$ oxidation should be longer than 20 minutes. 


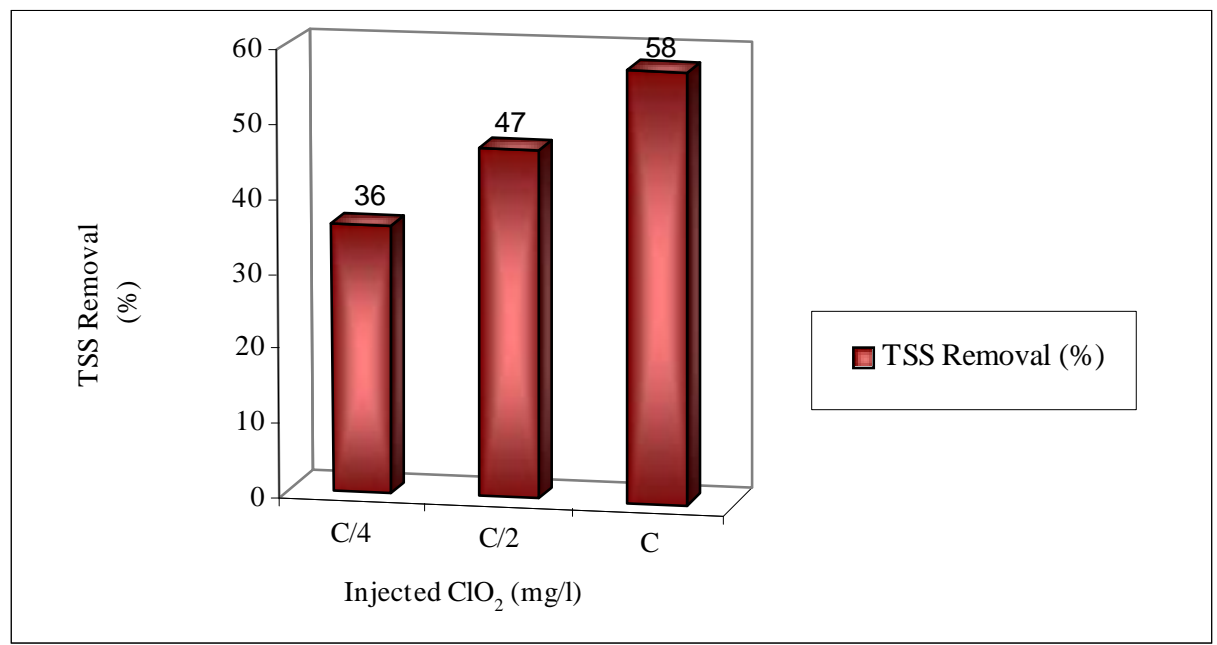

Figure 5: TSS removal as a function of injected $\mathrm{ClO}_{2}$ in contact time of 1 hour $(C=$ influent $C O D$ concentration $)$

\section{References}

Aiet, E. and M. Hernandez, Determination of $\mathrm{ClO}_{2}$, chlorine, chlorite and chlorate in water. AWWA, 64-69, 1984

APHA, AWWA and WEF, Standard methods for the examination of water and wastewater. $19^{\text {th. }} \mathrm{Ed}$., Washington DC., 1995

Eckenfelder, W. W., A. R. Bowers and J. A. Roth, Chemical Oxidation, Technomic, 2: 1-3, 1994.

Jackman, A. P. and R. L. Powell, Hazardous waste treatment. np: 195-208, 1991

Metcalf and Eddy, Wastewater engineering, treatment and reuse. $4^{\text {th. }} \mathrm{Ed}$., McGraw Hill, 12581261, 2003
Otterholm, H. and G. Jadesjo, Chlorine dioxides water treatment promise water. 21-22 2000

Reynolds, T. D. and P. A. Richards, Unit operations and processes in environmental engineering. $2^{\text {nd. }}$ Ed., PWS Pub., 751-752, 1996

White, G. C., Handbook of chlorination and alternative disinfectants. $3^{\text {rd. }}$ Ed., Van Nostrand Reinhold, 890-1039, 1992

WPCF, Wastewater disinfection. MOP-FD-10, $65-$ 69, 1986 
